\title{
O imagine a cărții în Însemnări de pe manuscrise și cărți vechi din Țara Moldovei, I-IV, un corpus editat de I. Caproșu și E. Chiaburu
}

\author{
Maria Lupu* \\ Facultatea de Litere, Universitatea „Alexandru Ioan Cuza”, Bd. Carol I 11, 700506 Iași, România
}

\section{Despre articol}

Istoric:

Primit 22 noiembrie 2014

Acceptat 10 ianuarie 2015

Publicat 17 iulie 2015

Cuvinte-cheie:

traducere

marginalia

paratext

\begin{abstract}
Rezumat
Contextul în care se desfășoară cercetarea este în cadrul preocupărilor noastre mai largi cu privire la evoluția mentalităților în perioada de după secolul al XVIlea. Scopul cercetării este de a identifica, într-o anumită măsură, felul în care se raportau la carte oamenii epocii respective. S-a impus lectura repetată și succesivă a însemnărilor, de fiecare dată cu alt scop, căutînd alt tip de date. Analiza și sinteza au fost principalele instrumente de operare, perspectiva fiind una diacronică. Drumul parcurs este de la particular la general, într-un demers inductiv. Cert este că, tipărită sau manuscrisă, cartea este factor activ în viața umană și se bucură de o considerație deosebită. Răspîndirea, ulterior circulația cărților, amplul efort de traducere din diferite limbi reflectă o efervescență culturală foarte mare.
\end{abstract}

\section{Introducere}

Elemente de paratext, de escortă a conținutului propriu zis al cărții, însemnările de pe vechile manuscrise și cărți se constituie într-o literatură distinctă cu caracter pluridisciplinar, fiind expresia sensibilităţii unei epoci în desfășurare. Fie că sînt evocate prilejuri de copiere, vînzare-cumpărare, danie, traducere etc. ale cărții, combinate cu întîmplări istorice, meteorologice, cataclisme naturale, boli molipsitoare, ele oferă, într-o oarecare măsură, o frescă a unei epoci trecute, fiind adevărate izvoare (unice prin specificul lor) pentru cercetarea din varii domenii. Dintre acestea se detașează, numeric, cele care au în centru cartea, furnizînd informații importante referitoare la copist, posesor, distribuție și circulație, preț, cititor, recondiționarea volumului, traducere, danie, răscumpărare, zălogire etc. în perioada 1429-1859.

\section{Cartea, dimensiune a timpului creștin}

Cărțile erau privite ca obiecte durabile. Însemnările sînt încredințate cărții fiindcă aceasta le asigură perenitatea. Într-o societate dominată categoric, pînă la un moment dat, de oralitate, scrisul devine, ca în mitul din Phaidros, un „leac al uitării și, deopotrivă, al neștiinței” (Platon, 2011, p. 126). Bucurîndu-se de o considerație morală deosebită prin mesajul creștin pe care îl conține, se manifestă credința că volumul/manuscrisul este destinat unei existențe de veacuri (Chiperi, 1996, p. 13). Această certitudine stimulează însemnările care, odată încredințate cărților, fixate prin scris, devin o punte spre neuitare, înfruntă timpul în căutarea unui interlocutor în generațiile următoare; de unde și leitmotivul prezent în majoritatea notelor infrapaginale, „să să știe”. Materialul pe care sînt scrise însemnările-cartea, obiect durabil—asigură acest dialog complex între generații, iar articolul de față este o dovadă în acest sens.

Raportată la timp, cartea evidențiază un sentiment profund religios al oamenilor epocii respective, conturînd, prin ipostaza ei în percepția comunităţii, o dimensiune temporală în sens creștin (Radosav, 1997, p. 75). Odată așezată în strană sau în altar, cartea de cult devine inamovibilă, neafectată de trecerea timpului (Ofrim, 2001, p. 129): „Stăpîna și cneaghina Theodora” a dat o Evanghelie mitropoliei din

*Adresă de corespondență: marioaralupu@yahoo.com. 
Maria Lupu

Suceava „neclintit în vecii vecilor, amin” (I, 24) ${ }^{1}$. Mitropolitul Teofan donează, și el, la mijlocul veacului al XVI-lea, o carte, „ca să-i fie lui amintire pentru nesfîrșiţii veci” (I, 57). Timpul cărții este uneori timpul lumii lui Dumnezeu (Radosav, 1997, p. 131). Astfel, ieromonahul Parthenie de la mănăstirea Bisericani cumpără Psaltirea „ca să fie în chilia mea, pînă cînd va milui Dumnezeu în această lume deșartă” (I, 157). Deoarece cartea este „vecinică pomenire” pentru sufletele donatorilor (II, 30), ea reprezintă „cheia” către lumea fericirii veșnice, o legătură între mundan și divin: cei care au contribuit la achiziția unui Chiracodromion sînt „scriși pi patruzăci di fili, spre pomenirea lor și a tot neamul lor, în veacul acesta și în celalalt ce va să fie” (III, 126). Astfel, cartea este integrată în complexul de credințe, practici și obiceiuri tradiționale menite să asigure mîntuirea sufletului, precum și o cale de consolidare a solidarității lumii celor vii cu lumea strămoșilor (Radosav, 1997, p. 76). Cartea este cumpărată „ca să fei odoru în veci feciorilor mei și nepoțîlor şi strănepoțîlor” (II, 304), cu siguranța că se va bucura de aceeaşi prețuire.

Însemnarea marginală este o altă dimensiune temporală. Scrisul reprezintă simbolul eternității. Opus permanent umanului efemer, la nivelul notelor infrapaginale se dezvoltă o tensiune între „mîna de țărînă” (sinecdocă pentru umanitate la modul general) și „slova veșnică”: „Și mîna care au scris va putrezi în groapă, iar cuvintele vor rămînea în veci, amin” (II, 222). Preotul Vasile Baltag consemnează numele posesorului „spre pomenirii și spre ținere de minte, că oamenii să pitrec, dar sfintele cărți rămîn” (IV, 392). Valoarea scrisului se poate întoarce uneori în defavoarea păcătoșilor. Astfel, într-o poezie-meditație pe tema morții de la sfirșitul secolului al XVIII-lea, păcatele nu vor putea fi nici „dosnicite”, nici tăgăduite, deoarece „sînt scrise prin izvoade/[...] Să rămîi în vecii” (II, 319).

\section{Atribute ale cărţii}

„Sfîntă și dumnezeiască” (II, 347), cartea era asimilată obiectelor de cult alături de alte obiecte prețioase care serveau ritualului religios, fiind inclusă în „catastiful de odoare bisericești” (I, 97) aparținînd tezaurului sfîntului lăcaș: „argintării, veșminte, cărți și alte lucruri” (IV, 103).

Cărțile conţin însemnări care le sintetizează valoarea. O Istorie a lui Tarlo este „vrednică de citit” (III, 472), o altă carte este „foarte iscusită și frumoasă” (III, 58), iar un Bertoldo i s-a părut lui Iordache Chirescu „atîta de interesătoare și bine tocmită”, încît l-a socotit vrednic „de o tălmăcire moldovenească” (II, 541 ). Aglomerarea de superlative juxtapuse sau coordonate copulativ arată uneori o retorică căutată: „preaînaltă, preaminunată și de mare și negrăit folos pricinuitoare carte” (IV, 479). Utilitatea cărții este frecvent afirmată în consemnările marginale. Un Mărgăritar este „de mult folos oamenilor” (III, 18) iar Divanul lumii cu înțăleptu este „foarti folositoari oricui să va îndeletnici a citi” (III, 364); apelativul „folositoare” ataşat cărții poate fi circumscris pedagogiei religioase, precum și utilizării volumului ca manual de învățare (Radosav, 1997, p. 27). Atingînd ambele dimensiuni umane, cartea este „folositoare sufletești și trupești” (IV, 94), dar mai ales „folositoare de suflete” (III, 480). În acelaşi registru spiritual, ea este „izbăvitoare de suflet” (I, 155), fiind „balțăm vindicatoriu din munca di veci și împărăția ceriului” (IV, 228), o poartă deschisă spre mîntuirea păcatelor.

Viziunea asupra cărții este uneori metaforizantă. Aproximativ într-o „definiție” metaforică, un Evangheliar este asimilat, în genul proxim, instrumentelor muzicale: „această [de] b(la)goslovie cu patru strune”, iar diferența specifică aduce lămuriri: „și cu tot dulcele glas alăută” (I, 475). Alteori se enunță mai întîi particularitatea lipsă: „cartea nu iaste lucru pămîntesc”, și se sustrage, deci, tehnicilor comune de a acționa asupra ei: „ca să-l cioplești cu barda”; antitetic, „iaste duhu datu de la $\mathrm{D}(\mathrm{u}) \mathrm{mn}(\mathrm{e})$ dzău”, instrumentul potrivit desăvîrșirii ei fiind rațiunea: „ca să-l lucrezi cu mintea” (I, 528). Este afirmată astfel ideea sacralității scrisului, cartea (religioasă) exprimînd o hierofanie (Radosav, 1997, p. 68), un obiect prin care s-a realizat manifestarea sacrului. Frecventă este și metafora cărții-floare, însă nu „îndegrab veștejitoare și putrezitoare”, ci „îndelung trăitoare și mirositoare [...] udate din rooa darului Duhului Sfînt” (II, 426)— care poate fi mirosită și gustată. Iar papilele gustative ale receptorului vor fi desfătate de „dulciața aceștii

\footnotetext{
${ }^{1}$ Datorită frecvenței, trimiterile la textele din Insemnări de pe manuscrise și cărți vechi din Țara Moldovei se vor face în felul următor: între paranteze rotunde se va nota numărul volumului cu cifre romane, urmate de numărul paginii cu cifre arabe.
} 
Svinte Scripturi” (I, 475), el și își va „adăpa sufletul” cu „multi dulci învățături” (III, 284), deoarece cartea este „izvor de miere” (II, 127) sau „dătătoare de miere și aur” (I, 166). În metaforismul medieval topos-ul cărții-hrană (răspîndit în literatura apuseană) își are originea în pasaje din Vechiul Testament (vedenia lui Iezechiel, a Sfîntului Ioan), în care bibliofagia este o formă de consubstanțialitate între om și carte (Ofrim, 2001, p. 213). Ceea ce Jack Goody numește „the drinking of the word” (Ofrim, 2001, p. 213), simbolul îngurgitării textului este o cale de a eluda distanța dintre cititor și textul scris.

\section{Copistul}

În covîrșitoarea lor majoritate, textele marginale cuprind însemnarea de copiere a manuscrisului respectiv. Manuscrisul este o prezență permanentă a epocilor în discuție, la început ca unic mijloc de multiplicare, învestit cu funcții noi ulterior. În opoziție cu imprimeriile, care sînt monopolizate de stat, auto-ediția manuscrisă reprezintă libertatea celor instruiți de a-și alege singuri lecturile și de a le răspîndi fără a recurge la instituția statului și fără a cere aprobarea unor instanțe politice sau ecleziastice (Barbu, 1996, p. 76).

De cele mai multe ori manuscrisul este semnat, ostenitorii scrisului nedorind să rămînă anonimi. Numele copistului-întreg și/sau cu diferite determinări care înlătură posibilitatea confuziei-urmează, aproape fără excepție, unor calificative (auto)denigratoare: se scrie Sintagma lui Matei Vlastaris „cu mîna multpăcătosului tahigraf, grămătic Damian” (I, 20). Modestia îmbracă forme stereotipe, însă uneori se remarcă prin crearea unor imagini expresive: „S-au scris di păcătosul Simion, cel mai păcătos dicît toți păcătoșii și mai rău dicît dracii și mai viclean și mai bețiv, curvar pre curva Sodomii, tîlhar, fur... și în vîrfu răutăților ajuns" (III, 474).

Semnătura de pe manuscris cuprinde foarte frecvent, din secolul al XV-lea pînă la jumătatea celui de-al XIX-lea, și o formulă specifică: Evanghelie scrisă „cu mîna multpăcătosului moldovean” (I, 13); „Scrisu-s-au această carte di această di lut păcătoasă mînă a me” (II, 392). Mîna devine adeseori „dreapta”: "S-au prescris prin osîrdie dreptii mele" (III, 360). Intenția fondatoare și opera aparțin, deopotrivă, unui fondator („ctitor”), însă execuția (sinecdoca „mîinii”) aparține meșterului (scriitor, în acest caz). În cultura medievală, mîna este izvorul a tot ceea ce ființează, însăși sursa creativității umane (Barbu, 1996, p. 100).

Foarte mulți copiști aparțin mediului ecleziastic, de la clerici mărunți pînă la înalte fețe bisericești. Alte cărți erau copiate de diferiți funcționari de cancelarie, deci scriitori de meserie: „S-au sfirșit Istorie Sfintului Avva Macarie. Martie 31, 1789, i proci. Logofăt Ilie Gligorcea” (II, 479), unde vechiul slav „,̦i altele" confirmă calitatea de scriitor de meserie, scrib. Însă copiștii se aleg și din rîndurile altor categorii ale societății; scriu diferite manuscrise (mari) dregători (vornici, cluceri, comiși, căminari, spătari), persoane încadrate în serviciul militar (căpitani), slugi sau copii de casă. Cei care scriu cărțile se numesc ei înşiși „scriitori” sau chiar „copiști”. De asemenea, trebuie menționat faptul că multe manuscrise au autoare, toate făcînd parte din mediul monahal: un Miscelaneu „scri-s-au de [...] nevrednica shimonahia Micdonia” (III, 2), iar un altul „s-au scris de Ipistimia monahia” (III, 112).

Scrierea se face la poruncă sau la îndemn și cu cheltuiala celui care comandă cartea. Mai ales cărțile din secolele al XV-lea și al XVI-lea se scriu sub patronaj domnesc, fie din porunca domnilor, fie a membrilor familiei domnești. Domnitorii inițiau și sprijineau activ înzestrarea bisericilor cu textele de cult necesare, dorind în acestea un susținător al puterii feudale (Tomescu, 1968, p. 27). Foarte multe cărți sînt scrise prin danie și poruncă voievodală, protagonistul fiind, în majoritatea cazurilor, Ștefan cel Mare: „Binecinstitorul și de Hristos iubitorul domn Ioan Ștefan voievod, domn al Țării Moldovlahiei, a dat de s-a scris acest Tetraevanghel" (I, 10). Dorința domnilor de a subvenționa scrierea de cărți se prelungește, mai rar însă, și în secolele următoare. Cărți se scriau și cu porunca și cheltuiala unor înalte fețe bisericești-episcopi, arhiepiscopi, mitropoliți: „S-a prescris această sfîntă Evanghelie cu dania și învățătura mitropolitului Teoctist din Suceava" (I, 36). Însă unele manuscrise, cu subiecte variate, erau comandate de diferiți boieri dornici să le citească, să le doneze, să le colecționeze în propriile biblioteci. Dar se scrie și pentru persoane apropiate: „am scris-o [...] fratelui meu mai mic și al doilea” (I, 39), iar cîteodată manuscrisele sînt copiate pentru folosința autorului însuși sau pentru copiii săi. 
Foarte frecvente în însemnări sînt formulările retorico-persuasive prin care copistul încearcă să cîștige bunăvoința și clemența cititorului; majoritatea scriitorilor își cer iertare pentru posibilele greșeli, invocînd tot felul de motive care le-ar putea genera. Predomină funcția conativă, centrată pe receptor, majoritatea acestui tip de texte intitulîndu-se, paratextual, „predoslovie cătră pravoslavnicii cetitori” (II, 23). Ca o prefață la îndurarea cerută cititorilor, copistul face aluzie la truda depusă, numindu-se pe sine „cel osîrdnic ostenitoriu” (III, 84) sau „iubitorul de ostenele” (II, 428). Tot copistul este primul care enumeră tipurile de erori posibile (în „prescriere” sau în traducere). Acestea se referă atît la formă cît și la conținut: „de veți afla vreo greșală, sau alunecarea condeiului, sau cu uimirea minții, sau cu netocmirea cuvintelor sau cu neorthografia meșterșugului, sau ori în ce chip” (II, 439). Captivante în acest tip de însemnări sînt încercările de justificare a greșelilor printr-un procedeu de largă circulație mai ales în Evul Mediu, excusatio propter infirmitatem (Stancu, 2006, p. 131). Deosebit de variate, unele sînt clișee preluate, altele însă se remarcă prin expresivitate și originalitate.

O serie de motive invocate de autorii de manuscrise pot constitui o clasă a adevărurilor general-valabile, aforisme foarte solicitate în acest tip de texte; fără a fi, totuși, banalizate de utilizarea excesivă, aceste aserțiuni păstrează ceva din farmecul epocii. Majoritatea sînt metafore plastice referindu-se la imperfecțiunea umană, comparații cu elemente naturale (cerul, marea) sau divine (îngeri, serafimi, heurvimi). Amintim dintre aceste maxime: „Căci nime în lume născut nu poate fi negreșit” (III, 193); „Cum nu este cu putință să fiie ceriul făr-de nouri și marea fără de valuri și pămîntul fără de scîrbe, așa nu este cu putință să nu fie omul fără de greșală.” (II, 23). Se accentuează frecvent opoziția uman-divin: „Că eu de îngeri sînt departe; / Că om fiind eu, muritoriu, / N-am putut a fi negreșitoriu” (IV, 76). O altă categorie de cauze care provoacă greșelile transcrierii sau ale traducerii se referă la neputințele fizice ale autorilor. Ieromonahul Mitrofan enumeră „multe neputințe și slăbiciuni” ce cuprind tot trupul scriitorului: „ochii uneori se painjiinesc căutînd, socotind și numărînd mulțimea cea fără de număr a slovelor. Mîna dreaptă slăbește țiind condeiul; după cap îl doare pentru multa plecare a grumazilor; spatele îl dor, pentru multa plecare gîrbovindu-să; picioarele îi amorțăsc, răvenindu-să de pămînt; pieptul carele să razimă de masa pre care scrie, ca cu cuțite săgetat și pătruns iaste; capul, turburîndu-se creierii, cînd îl rădică în sus să face ca un amețit; scaunul, carele tuturor știut iaste că oricine cînd șade pe scaun odihnă cîștigă, iară scriitoriul nu odihnă, ci zămorîre trupul dobîndește; tot trupul, pînă nu să întinde, nu se îndreptează” (III, 166).

Vîrsta este, şi ea, citată în disculparea copistului. Pe de o parte, este invocată vîrsta înaintată: „mai vîrtos fiind și la 60 de ani a ticăloasii vîrstii mele.”(II, 304). Pe de altă parte, și tinerețea poate dăuna corectitudinii manuscrisului. Retrospectiv, la maturitate, autorii remarcă greșelile făcute. Astfel, „fiind în vîrstă tînără și copilărească, mintea abătîndu-să la multe deșărtăciuni” (III, 46), Theofil ierodiaconul cere iertare pentru greșelile săvîrșite (la data însemnării fiind de 69 de ani). Firesc, slăbiciunile care generează erorile din manuscris sînt și de natură psihică, spirituală, nu numai fizice. La un prim nivel, de maximă generalitate, umanul este, inevitabil, asociat imperfecțiunii: „că sînt și eu om pe pămînt, împletit în multe feliuri de păcate” (I, 316). Urmează particularizarea: în modestia lui fiecare autor se autocaracterizează în negativ; involuntare („nu din voie ostinenții mele”), greșelile se datorează „nesăvărșirii slabei minții meale” (I, 494), lipsei învăţăturii (II, 190) sau a înțelepciunii (II, 177), a întunecării minții din cauza păcatelor (II, 254).

Vremurile tulburi reprezintă un alt argument care vine în sprijinul mînuitorului de condei: „că în vremea răzmiriții o am scris, fiind cu muncile împărțite pentru înfricoșări” (III, 526). Împrejurărilor istorice neprielnice se adaugă şi diferite necazuri personale: „și am scris în multă strîmtoare, și în familie şi în grea muncă” $(I, 39)$. Alteori eventualele greșeli săvîrșite în scriere au ca pretext cărțile-sursă. Călugărul Eleazar se justifică: „,izvodul a fost neîndreptat și eu spre aceasta neputincios”, deci a scris-o „cu anevoie” (I, 35). În alte cazuri de vină sînt slovele, care se aseamănă: „Știu că multe greșale voiu fi făcut, unele pentru asămînările slovelor, precum $a$ de cătră $l, b$ de cătră $v, i$ de cătră $n, e$ de cătră $s^{2}$, care pentru puțina lor

${ }^{2}$ Deși buna metodă filologică ar cere să dăm caractere chirilice și nu caractere latine, întrucît am operat cu o ediție de cea mai mare încredere, am citat întocmai din corpusul care stă la baza cercetării. 
despărțire s-au făcut greșală” (III, 612). Nu în ultimul rînd, graba scrierii manuscrisului își are partea sa de vină în strecurarea greșelilor: „Cetitorul mă va ierta fiindcă cu grăbire am scris” (III, 545).

În spirit creștin, copistul îl roagă pe cititor să îi ierte greșelile făcute „Ca și Dumnezeu să-i dia tot binele, / Aici și în veacul cel viitoriu” (III, 11), pentru ca și el, la rîndul lui, să ia „iertăciune de la preavecinicul și preaputernicul Dumnezeu” (I, 431). Pe de altă parte, autorul roagă „pe cine va ceti” să nu îl judece, ci, mai întîi, „să socotească izvoarele” pe care a „îmblat” (I, 259).

Parcurgînd însemnările, se pot face unele observații în ceea ce privește traducerea. Mai ales, „tălmăcirea” conținutului sacru întîmpină anumite dificultăți, enunțate de către traducător. Majoritatea textelor se referă la efortul laborios cerut de acest act: „cu multă trudî și osîrdie le-au scos pre limba românească di pre a greceștii limbă și slovenești” (I, 310). Cel care tălmăcește textul este conștient de faptul că trecerea dintr-o limbă în alta nu este o simplă echivalare de conținut; astfel, el este nevoit să nuanțeze, să ajusteze traducerea, să revină asupra unui paragraf cu lămuriri suplimentare: „La acest rîndișor nu prea lesne să înțălege cum am tălmăcit rumânește fiindcă limba noastră iaste scurtă și puterea cuvîntului ellinesc prea adîncă” (II, 219). Autorul se raportează critic la limba-ţintă, datorită permanentei comparaţii a celor două limbi, greaca pe de o parte, și româna de cealaltă. Concluzia nu este măgulitoare pentru cea din urmă: aceasta este o limbă care nu are exercițiul cuvîntului divin, ale cărei posibilităţi nu au fost încă relevate. Incapacitatea cuvintelor românești de a capta semnificațiile profunde ale celor „ellinești” este suplinită cu o explicație: „Ci pentru ca mai lesne să să înțeleagă, să zicem așa” (și urmează o altă variantă a traducerii). Monahul Rafail traduce, și el, din „cea prea cu anevoie de tîlmăcit limbă ellinească pre a noastră limbă proastă rumânească” (II, 211); iar mitropolitul Veniamin Costachi o numește „săraca limbă romanodachicească sau moldovenească” (III, 517). Limba română nu este încă, în aceste veacuri de frămîntare culturală, îndeajuns de mlădioasă pentru a surprinde conținuturile religioase. O însemnare de la începutul secolului al XVIII-lea de pe Codicele voronețian: „Această carte au fost scrisă pe rumănie și nu-i bună de nemică” (I, 466) consideră limba română nepotrivită pentru vehicularea sensurilor sfintelor cărți. Limba vorbită de popor este, în secolul al XVII-lea, considerată încă incompatibilă cu un conținut abstract ca cel religios, acesta putînd fi vehiculat numai de limbile clasice (Panaitescu, 1971, p. 343); traducerea din slavonă în română a cărților sfinte este în acest secol o îndrăzneală mare, acestea fiind privite cu neîncredere și cu teamă de mînia lui Dumnezeu.

Referirile la română ca limbă țintă pot reprezenta un argument în favoarea unei conștiințe naționale și a unității limbii. În majoritatea cazurilor, moldovenii consideră limba pe care o vorbesc ca fiind românească: s-a tălmăcit „pre limba rumănească” (I, 500), se scrie „pe romănie” (I, 488) sau „pre înțelesul rumânescu” (II, 107). În Moldova, diferite cărți se traduc „spre folosul cel di obști al neamului românesc” (IV, 246), și nu pentru cel moldovenesc. Faptul că în epocă se pune semnul egal între limba moldovenească și cea românească este afirmat deschis chiar de autorii traducerilor: o Alfavita este „mutată” din „limba leșească și pre limba noastră moldovenească sau rum(â)nească” (I, 294). Cel mai probabil, noțiunea de limbă moldovenească se utiliza paralel și cu același înțeles cu limba românească (Stoicescu, 1983, p. 69), demonstrînd astfel unitatea limbii vorbite în Țara Românească și Moldova, unde există o singură realitate etnică: cea românească. În secolul al XIX-lea, limba românească este sinonimă cu limba patriei: un Tractat dogmatico-polemic „s-au tălmăcit (...) din limba elinească întru a patriei” (IV, 180); Alexandru Beldiman a tălmăcit „de pe franțuzasca limbă în limba aceasta a patriei noastre” Istoria viteazului Raimond și a iscusitei Mariana (III, 623).

Larga difuzare a cărții manuscris, numărul mare al copiștilor și al traducătorilor dovedesc că în perioada cercetată, pe teritoriul Moldovei se desfășura o activitate culturală intensă; exista o tradiție cărturărească și se formase, prin acești copiști, pisari, dieci, grămătici o clasă de oameni ai cărții (Ciobanu, 1947, p. 124).

\section{Posesia cărţii}

Un număr apreciabil de însemnări făcute de-a lungul timpului pe manuscrise și tipărituri informează asupra proprietarului cărții respective. Adevărate „acte de posesiune”, aceste ex-librisuri de pe cărțile vechi 
fac foarte uşoară apropierea dintre carte și om peste timp și spaţiu (Troia, 2005, p. 5).

Uneori, acest tip de însemnare este lapidară: „S-au făcut proprietate a lui Gheorghe Asachi. 1815” (III, 352). Frecvent, proprietarul este colectiv, lăcaşurile de cult sau comunitățile săteşti: o Voroavă de întrebări și răspunsuri întru Hristos (București, 1765) este semnată: „Din cărțile sf(intei) m(ă)n(ăstirii) Rîșca” (II, 153); „Să (se) ştie această sfîntă şi dumnezeiască Pravilă că este a satului, a Colţilor” (I, 237). În perioada cercetată, consemnările marginale dezvăluie existența a numeroase biblioteci, atît particulare, cît și clericale. Astfel, sînt frecvente formulările de tipul: „Din numărul cărților arhimandritului Isaia” (III, 161); „Din biblioteca mea de la Rotopănești.” (IV, 233). Se profilează adevărați colecționari: Neofit Scriban, Nicolae Istrati de la Rotopănești, Gheorghe Asachi. Destule însemnări infrapaginale sînt constituite de liste de cărți care se află în posesia mănăstirilor. Sînt adevărate inventare de bunuri materiale: „Izvod de toate cărțile și acareturile mari și mici, cîte să află pe lîngă mine” (III, 18).

Cartea, avînd caracter de marfă, se supunea legilor economice (Chiaburu, 2005, p. 96). Cercetarea însemnărilor infrapaginale relevă faptul că prețul cărților a reținut în permanență atenția, autorii consemnînd în detaliu cine, de unde și cu cît a cumpărat volumele.

Parcurgînd corpusul de însemnări, reiese cu evidență faptul că era nevoie, în multe cazuri, de eforturi colective pentru a achita contravaloarea cărții. Foarte multe note marginale constau în enumerarea celor care au contribuit la cumpărarea volumului respectiv: un „izvod de cumpărătură” al unui Penticostar înregistrează că „2 lei pol, 6 bani, au dat Mărgăreștii; 1 leu pol au dat Cheptăneștii; 4 pol, 8 bani, au dat Andrei căpitanul Săhăidac, 1 leu pol, 6 pol au dat, amin, streini. Fac 6 lei 8 parale” (II, 18).

Prețurile cărților au fost exprimate de-a lungul secolelor în monede diferite, dezvoltînd un bogat cîmp semantic monetar. Astfel, de la sfîrșitul secolului al XV-lea și pînă la începutul secolului al XIX-lea, prețul cărților se achita în tot felul de bani, de diferite origini și cu diverse valori: aspri, carboave, costande, cruntaliri, florinți, galbeni, groși, lei, ludovici, ruble, parale etc. Prețul cărții implică și acțiunea de vînzarecumpărare a acesteia. Cercetătoarea Elena Chiaburu separă conceptul de „distribuție” de cel de „circulație” a cărților. Astfel, în timp ce primul aparține economiei, presupunînd „o cantitate mare a mărfii difuzate și, obligatoriu, structuri organizate”, cel de-al doilea începe „atunci cînd proprietarul inițial se desparte de ea, prin vînzare, donație, moștenire” (Chiaburu, 2005, p. 145). Distribuția ține de momentul imediat următor al ieșirii cărților de sub tipar, în care produsul finit ajunge la destinatari.

Forma principală de distribuție a tipăriturilor a reprezentat-o vînzarea. Se practica desfacerea mărfii en detail direct din atelierul tipografic. Cartea românească de învățătură (Iași, 1643) este cumpărată în același an „din tîrg din Iași, de la tipariul domnesc” de către „Mierțe și gazda sa, Isipa, și fiul său, popa Ion” (I, 203), iar preotul „Ioan Vasilovici din Crătești” cumpără o Carte folositoare de suflet (Iași, 1819) „din tipografia sfintei Mitropolii în Moldaviia” (III, 567). Clerul era și el implicat în distribuția cărții. Mihalcea Durac „ce au fost logofăt mare” a cumpărat o Carte românească de invățătură pentru patru galbeni de la „Varlaam mitropolitul Sucevii” (I, 204) iar o Psaltire (Iași, 1807) este cumpărată „din Tîrgu Iașului, di la poarta mitropolitului, la anu 1807 mai 22” (III, 25). Întreaga ierarhie bisericească era implicată în distribuirea cărților de cult mai ales, care se vindeau comunităților religioase cu titlu de obligativitate. Verbele la diateza pasivă „s-au dat”, „s-au împărțit” nu trimit, în aceste însemnări, la actul donației, ci la acela al vînzării, însă cu ceva în plus: caracterul de obligație. Din porunca mitropolitului cărțile de cult ajungeau la sate: un Penticostar (Iași, 7261), tipărit „cu blagoslovenie și cu toată cheltuiala sfinții sale chir Iacov, fiind mitropolit a toată Moldovlahia” „s-au dat” la biserica din Botești „și au fost orînduiți de au plătit ctitorii și preoții şi poporănii” (II, 30). Tipăriturile coborau pe scara ierarhică (Chiaburu, 2005, p. 158), fiind trimise la episcopii. Un Penticostar (Iași, 1753) „s-au orînduit de măria sa Vodă, cu cheltuiala sfinției sale părintelui mitropolitului Iacov și cu osteneala sfinției sale părintelui episcopului... s-au dat pe la sate" (II, 19). Mai departe treceau prin mîna protopopilor: un Triod (București, 1796) este cumpărat de „oamenii din Straja de la mîna protopopului Toader Rămășcan drept 20 lei”. Blagocinii și preoții erau uneori ultima verigă a acestei distribuții, luînd cărțile de la protopopiate pentru a le da în sate: „S-au dat din porunca stăpînirei duhovnicești la satul Ruseștii Vechi. Blagocin preotul Constantin Cujbă” (IV, 194). Uneori obligativitatea cumpărării venea dinspre celălalt patron al tipografiei, domnul. Un Apostol 
(Iași, 1756) „și altă carte ci să cheamă Anfologhie” sînt cumpărate în același an „din porunca mării sale, lui Costandin ficiorul lui Mihai Cehan v(oie)voda” de către "noi, oaminii cari mai gios ne-am pus numirile în rîndu" (II, 59). O altă modalitate de desfacere dirijată a cărților este vînzarea lor la dughenele de pe lîngă tipografie sau Mitropolie, uneori împreună cu articole de „brașovenie”. Descrierea Moldovei (M-rea Neamț, 1825) este „cumpărată cu cinci lei de la o brașovenie din poarta Mitropolii” (III, 581).

Începînd cu a doua jumătate a secolului al XVIII-lea, textele marginale consemnează cărți procurate de la negustori. Astfel, o Liturghie (Iași, 1747) este cumpărată „de la un vînzător de cărți, Dumitru Lesne, împreună cu alte cărți” (IV, 276). „Lazăr de pi Tazlău” este atestat ca „neguțător de cărți, de li aducea din Țara Rumânească din București și li neguțătorea, adică le vindea mai scumpu aicea în Țara Moldovii” (II, 307). Este posibil ca aceștia să fie doar colportori de cărți, îndeplinind ceea ce Chiaburu (2005, p. 146) numește „circulația populară” a cărții, și nu pe cea specializată.

Tipografii sînt și ei agenți ai distribuției cărții, vînzînd unele exemplare primite ca plată (Chiaburu, 2005, p. 163). Astfel, un Triod (Iași, 1747) a fost cumpărat, chiar în anul apariției, de „Gheorghii” de la „Duca Sotiriovici tipograful” (I, 543).

Cărțile mai pot fi achiziționate și la licitație: un Minei „și cu soțiile lor unsprezăci” sînt cumpărate de ,jupănul Gheorghie blănar, la sultan-mezat” (III, 383). Faptul că o carte poate fi scoasă la licitaţie de autorități înseamnă că ea poate fi și confiscată. Acest lucru îl demonstrează și însemnările, argumentînd, o dată în plus, valoarea mare a cărților în perioada discutată. Unele cărți sînt confiscate din cauza neplății unor dări: Tîlcuirea liturghiei (Iași, 1697) „s-au luat zaloc de la un popa de la Podoleni, pentru 25 parale, dijma fînului" (II, 103).

Circulația cărților începe atunci cînd „proprietarul inițial se desparte de ea, prin vînzare, donație, moștenire" (Chiaburu 2005:145) la o distanță temporală de momentul apariției. Vînzarea cărților se făcea, în foarte multe cazuri, de către persoane aparținînd mediului monahal dar și de către diferiți mireni. Printre cumpărătorii de carte s-au aflat comunitățile sătești: „Acest Pinticostar, dinpreună cu un Minei, le-am cumpărat noi, satul Angheleștii” (III, 132). Cei care contribuiau la cumpărarea unei cărți erau numiți „ctitorii sfintii aceștii cărți” (II, 164) și, aproape fără excepție, cărțile erau donate bisericii satului. Strădaniile colective de procurare a cărții sînt acte culturale care arată o anumită atitudine și mentalitate, expresie a apartenenței la aceeași comunitate de limbă și credință (Danielopolu \& Demény, 1985, p. 121). Și lăcașurile de cult sînt cumpărători fideli ai cărților: un Penticostar (Iași, 1753) „s-au cumpărat de noi, epitropii mănăstirii Sfîntului Spiridon, cu bani mănăstirii” (II, 178). Printre cumpărătorii particulari se numără atît clericii, cît și mireni cu diferite ranguri sau ocupaţii (de la țară sau de la oraș). Cel mai adesea, cartea era cumpărată pentru a fi, imediat, donată ,pentru iertarea păcatilor lor, părinților lor și a tot neamul neamurilor lor” (IV, 468). În multe cazuri, însă, cartea cumpărată era destinată uzului didactic: „pentru învățătura preiubitului fiu al meu” (III, 433) sau avea altă finalitate: „spre a mea îndeletnicire și folos” (III, 435); „ca să-i fie odor lui și copiilor lui” (II, 26); ieromonahul Silvestru cumpără „fiindcă foarte am iubit a avea cărți pentru mîngîierea mîntuirii sufletului” (II, 353).

Dania cărților-manuscrise sau tipărite-a fost un fenomen de amploare între secolele al XV-lea și al XIX-lea, ea constituind atît o formă de distribuție gratuită a cărților, cît și una de circulație. Reprezintă cazuri de distribuție gratuită daniile voievodale sau ale înaltelor fețe bisericești (cărora, ca patroni ai tipografiilor, la momentul apariției unei cărți, le revenea un număr de exemplare); celelalte cazuri de dar al cărții ilustrează un aspect al circulației și răspîndirii ei.

Daniile domnești au atît o importanță culturală, cît și una politică. Un Antologhion (Iași, 1755) este distribuit gratuit „din poronca mării sale lui vodă” „pe la bisărici” (II, 49), fiind probabil din stocul personal al voievodului. Daniile depășesc granițele țărilor, stabilindu-se relații culturale între țările române: "Costandin Mihai Cehan Racoviță voievod, domn și oblăduitor a toată Ungrovlahiei” dăruiește ,această sfîntă Psaltire iaste afirosită la sfîntul schit ce să numește Oraețul, din județ Neamț” (II, 21), sau între țările române pe de o parte și diferite centre religioase (ca Muntele Athos) pe de alta. Unii dintre marii prelați s-au remarcat prin numeroase danii. Mitropolitul Dosoftei dăruiește Viețile Sfinților (Iași, 1682-1686), „fiind în bejenie printre străini”, unei mănăstiri „a Petridului” (I, 307). Ilustrînd relațiile culturale dintre 
Maria Lupu

țările române, mitropoliții și domnii își dăruiau unii altora din cărțile tipărite sub patronajul lor. Astfel, Dosoftei dăruiește, la rîndul lui, o carte primită de la „sfinția sa frate, mitropolitul de Ungrovlahia, chir Teodosie” „sfintei Mitropolii ceștii noauă, ce-i zîc Beserica Albă” (I, 294), iar „măriia sa Ioan Constandin al doilea B(asarab) voievod, domnul și oblăduitorul Țării Munt(enești)” dăruiește o Biblie „sfinții sale părintelui chir Dosoftei mitropoli(t) Țărîi Moldovei” (I, 314). Clericii de rang mic făceau și ei donații de cărți, între ei, către diferite lăcașuri de cult, către biserici sau unor mireni. Însă cartea era donată și de persoane din afara lumii monahale: deoarece Ion, „care au fost slugă” la Ieroftei, ,au slujit cu dreptate, [...] au fostu ca un fiu, iar nu slugă”, primește de la stăpînul său ,această carte ce s(e) cheamă Psaltire” (I, 414). Donatorii sînt extrem de numeroși, majoritatea însemnărilor avînd ca subiect cartea constituind exprimarea daniei; aceștia donează bisericilor, școlilor, persoanelor particulare, mentorilor.

$\mathrm{Cu}$ rădăcini într-o mentalitate profund religioasă, dania de carte este un act de pietate și gest de devoțiune (Mazilu, 2001, p. 285), ea făcîndu-se „pentru sufletul morților și sănătate viilor” (I, 443); să fie pomană donatorilor „și feciorilor lor, și părinţilor, și moșilor și strămoșilor” (I, 446). În toate societățile și în toate timpurile, însă, darul nu este un bun inert, ci atrage în mod necesar după sine noțiunea de credit, el trebuie înapoiat cu dobîndă (Mauss, 1993, p. 114). Darul conferă celor două „părți” aceeași natură, creînd o legătură bilaterală, foarte puternică pentru amîndoi: cel care primește (în speță, Dumnezeu) se situează într-o poziție dependentă de cel care oferă (donatorul) (Mauss, 1993, p. 159)—primul „datorează” celui din urmă mîntuirea. Actul donației de carte intermediază o apropiere a omului de divinitate, prin pomenirea și eternizarea numelui donatorului. Prin cartea dăruită bisericii creștinul este convins că iese din păcat, că lucrează pentru mîntuirea sa: „pentru ușurare sufletelor noastre și a părinților noștri, și mai ales pentru răpăusatul fiiu nostru Pașcu” (II, 127); „pentru sufeltul mieu” și „, tot neamul nostru în veci, amin” (IV, 76). Cartea religioasă, intercesor în raportul dintre om și divinitate, devine un sprijin escatologic: „și să fie ajutor în ziua judecății cumplite” (I, 86).

Cartea se transmitea din generație în generație, putînd fi lăsată moştenire. Cartea se moștenește, în primul rînd, de către copii: „să fie a feciorilor noștri” (II, 223). Însă copiii nu pot moșteni oricum cartea, diferite clauze restrictive impunînd anumite condiții. Știința de carte este una dintre ele: „<Cuvintele lui Teodor Studitul (Rîmnic, 1784) > va rămîne la fii mei care Dumnezău îi va răndui și care dintr-înşi va ave evlavie la citire sfintelor cărți, aceluie să rămăi” (III, 610). În altă parte succesorii sînt numai bărbații, „fetele și ginerii și oricini di partea fetelor treabă cu cartea să nu aibă” (IV, 307). Dacă fetele nu moșteneau cărțile (preferați fiind „feciorii”), ele puteau primi cartea ca zestre dacă se măritau cu un preot: „Această Evanghelie au fost mai înaint(e) vreme a lui popii Racoviță, iar după ce au măritat pe fiica-sa, pe Maria, fata cia mică, s-au dat și cărțăle cîte au fost a preotului (...) ginere-său” (I, 508).

Prin împrumut, cărțile circulau de la un cititor la altul. Unele cărți se împrumută „pentru treaba învățăturii” (I, 406), altele pentru simpla lectură: „am avut cinsti să-mi dei dumneaei cucoana Ileana Beldiman acesti istorii s-o cetescu" (III, 594), altele pentru a fi copiate (III, 187).

Fiind și valori materiale, cărțile erau adeseori furate de către hoți de rînd sau de către năvălitori. $\mathrm{O}$ însemnare deosebit de interesantă îl are autor pe stolnicul Iordachi, care povesteşte, pe „Leatopisăţul Ţării Munteneştì”, cum acest volum „a fost al mieu şi l-au furat dumn(ealui) Iordachi Balşu vor(nic)” (aşadar de o persoană bine situată în societate). Sînt notate şi împrejurările în care a fost săvîrşit acest act: „Că mi s-a furat acest Letopisăț într-o zi de luni, fiindcă venise şi dum(nealui) la casa me”. În continuare spune că, în ciuda faptului că l-a găsit, nu îndrăzneşte „a-i zice, dumnealui fiind boieru mare şi bătrîn” ( II, 10). Speră totuşi ca boierul, citind cele scrise, îi va înapoia cartea. Alt hoț consemnat este „preotul Pintelei ot Sveti Dimitrii” care a „furat” un Penticostar al „bisăricii Curălari din Iași” — găsit de „preot Axinte ot Sveti Vasăli” și „poprit” pînă îl va arăta mitropolitului (II, 390) iar un Minei pe luna august gr. (Constantinopol, 1843) al bisericii Sfîntul Spiridon ,au fost pierdut doi ane și s-au adus iar(ă)şi de către fur la an 1856 iunei $17 "(I V, 502)$.

Nu o dată, posesorul cărții trebuie stabilit prin judecată. Evanghelia (București, 1723) cumpărată atît de preot cît și de „poporăni” stîrnește nemulțumire, astfel încît au mers „la sfinția sa Nichifor mitropolit și ne-am giudecat" (II, 74). Tipograful Petru Ecard din Cernăuți nu recunoaște că a primit 14 lei pentru un 
Strastnic (Blaj, 1804), „n-au vrut să dea carte aceasta nicecum” și „apoi cu mare greutate o au scos Gavriil Ilisăi de la acel vînzător" (III, 288).

Foarte multe însemnări conțin informații despre istoria frămîntată și încărcată a cărților răscumpărate. Un Tetraevanghel a fost „trimis” în Țara Ungurească de la mănăstirea Humor pentru a nu cădea în mîinile tătarilor. Găsit acolo de Petru voievod, acesta l-a luat cu sine în „T, Tara Turcească”, „și încă și la T,arigrad”, pentru ca, ulterior, fiind „dăruit cu cunună împărătească” și întorcîndu-se ,în preaslăvita sa cetate de scaun, Suceava”, să ajungă și cartea, încheindu-și periplul, la mănăstirea Humor (I, 53).

\section{Cititorul}

Unele însemnări marginale-cele cu un conținut informațional complementar textului-se constituie în adevărate elemente de paratext. Un paratext de factură specială, totuși, deoarece toate notele infrapaginale care se înscriu în această clasă aparțin, în totalitate, cititorilor biografici, situîndu-ne, din punct de vedere pragmatic, în planul empiric (Stancu, 2006, p. 85). Astfel, în primul rînd, se încadrează în această arie însemnările cu valoare de predoslovii ale copiștilor (care sînt primii cititori ai cărților pe care le „prescriu”), prin care încearcă, mai ales, să cîștige bunăvoința unor cititori ulteriori. Aceste texte sînt, în același timp, atît o retrospecție a lecturii, cît și o anticipare a unor lecturi viitoare (ale unor cititori diferiți). Copistul se adresează reverențios unui cititor abstract, invitîndu-l, în mod pragmatic, la un dialog. Acest lucru se face cu utilizarea persoanei a II-a verbală şi pronominală, a imperativului și a adresărilor directe în vocativ, predominînd funcția conativă. „Pravoslavnicului cetitori” (II, 21) îi este invocată, într-un mod retoricopersuasiv, clemența. Sînt recurente formulările de tipul: „cetiți pre cartea aceasta și cu blîndețe îndireptați” (I, 260), „cetind acestea și de veți afla greșit nu vă grăbireț(i) a cleveti, ce îndreptați” (I, 317). Se cere nu numai îngăduința, ci şi participarea efectivă a cititorului la revizuirea şi îndreptarea cărții. Provocat la lectură-„Iubite întru Hristos cetitoriule [...] să nu-mi lenevești a ceti și aceste folositoare de suflet” (II, 94) —se mizează pe un cititor activ: „Pără aicea am găsit de am izvodit acest Litopisăț, dar de aicea înainte, urmașii mei cercetînd vor afla” (II, 163). Există chiar posibilitatea ca tălmăcitorul cărții să fie influențat de „pofticioşii cititori”: interesul acestora, care „,vor căuta pe tomul acesta cu silință”, îl va face să „nu se lenevească” și să traducă şi al doilea volum din Halima (III, 209). Un cititor excesiv de critic este avertizat de Alecu Beldiman că „,este lesne a huli, crede-mă, oricari poate / pricină ca să găsască, prin prepus sau cu dreptate”, însă „crede-mă, c-a huli îi drag celui de nemică, / carile c-a fi hulit nu-i pasă, nici ari frică” și se oferă, polemic, și o soluție: „de nu-ți place lecuire este, ca să nu cetești” (III, 117).

În al doilea rînd, sînt elemente de paratext notele cititorilor efectivi, empirici. Aceștia își trec numele (cu epitete voit modeste: „eu, mai nevrednicul între cititori”, II, 440), țin să informeze că au citit cartea în întregime („din scîndură-n scîndură”, II, 252), că au recitit volumul respectiv, că au „înțeles ci zîce” (III, 476) sau, dimpotrivă, „nimică n-am înțeles dintru dînsa” (III, 324). Însemnările au uneori în prim plan un scurt comentariu referitor la conținutul cărții glosate. Se pare că destinatarul a acceptat efectiv provocarea la dialog a autorului / copistului, oferă un răspuns, și va intra, la rîndu-i, în dialog cu cititorii ulteriori. Efect al lecturii, aceste texte conțin mici rezumate ale volumelor, referiri la structura lor, impresii despre importanța și scopul cărții, despre mesaj, despre adevăr sau ficțiune în carte, sfaturi de lectură, satisfacția sau nemulțumirea generate de finalul cărții sau diferite judecăți de valoare. Din ce în ce mai atenți la filtrarea opiniilor existente, cititorii se raportează critic la conținutul cărții, sistematizează informația, îşi exprimă opinii. Discernămîntul dovedit de unii cititori (ai cărților populare) este ilustrativ pentru atitudinea critică cu care ei încep să se raporteze la volum, precum și pentru faptul că receptorul a devenit o instanţă activă, care comentează și opinează pe marginea textului.

Găsim, astfel, pledoarii apologetice pentru adevărul celor citite-veridicitatea volumului Archirie și Anadan este proclamată și de „Simion Popovici ot Borca”, căzînd în sofismul autorității: „Pentru toate cele ci să află aicea scrisă, nimi să nu să îndoiască, căci mii nu-m trebuiește ca să zic minciuni, ci pe cum am aflat de la filosofi cari scrii și sînt vrednici de credință” (IV, 36). Dimpotrivă, „Ion Cărji ban” pune la îndoială adevărul evenimentelor relatate în Alexandria: „am isprăvit și eu de citit această cărticică a 
marelui împărat Alexandru Machedon și de vor fi adevărati toati căti să cuprind, cu adivărat că ești de minuni”, recunoscînd, totuşi, un sîmbure de adevăr: ,însă oaricum tot au fost cevaş” (III, 579). Noul gust pentru lectura din varii domenii, înmulțirea lecturilor frivole, necanonice, îl fac pe un cititor să exclame, dramatic și autoironic: „Vai mie, înnegritule suflete, pînă cîndu de la răutăţi nu mai curmezi! Pînă cîndu vei tot citi la Istorie lui Erotocrit și a Aritusii și altora ca acestora? Cu aceste digrab vei merge la raiu, cu cerga în capu. 1835 ghenar 18" (IV, 113).

Alte însemnări se constituie în sumare recenzii ale cărților respective. Istoria lui Zalmis și a Elvirii stîrnește nemulțumirea Catrinei Conachi; după ce își exprimă părerea la modul general, cartea fiind „foarti frumoasă, bini tălmăcită di cumnatu Alecu”, „dar statornicie acestor doi amorezi au fostu nisuferită, mai vîrtos pentru că dorința loru au rămas fără fericire în sfîrșitu” (III, 594). Cîteodată, cititorul oferă indicații referitoare la actul lecturii, la efectele acesteia, la atitudinea față de carte, la valoarea spirituală a conținutului, la atenția acordată, raportîndu-se critic la carte. Lectura este instructivă (Radosav, 1997, p. 59),

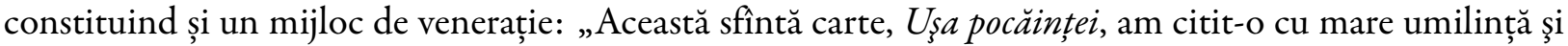
atîta plăcere am citit, cu foloase cuvinte cele aparte, (...), că eu cu toată seama am citit” (IV, 353). Uneori însemnarea indică un efect al lecturii, accentuînd pe sentimentul religios: „şi foarte m-am întristat de cuvintele înfricoşatelor munci ale iadului care sînt într-această sfîntă carte" (II, 149) sau dă un sfat pentru un viitor cititor: „şi cine se va sili, să o citească cu evlavie” (I, 168). Datorită conținutului ei, de cele mai multe ori religios, precum şi a valorii sale, lectura şi scrierea cărţii sînt acte care pot fi purificatoare (izbăvitoare, salvatoare): „şi să-l ierte Dumnedzău pe cine au făcut-o sau au cumpărat-o şi să mă ierte Dumnedzău şi pe mine” (I, 310). "Şi cini veți citi aice di la mila lui Dumnezău să aveţi daruri şi iertare păcatilor" (II, 355), cititorul intrînd într-un dialog virtual atît cu copistul cărţii, retrospectiv (răspunde la rugămintea acestuia de a se ruga pentru păcatele sale), cît și prospectiv, cu cititorii ulteriori.

O altă categorie de însemnări conține comentarii referitoare la forma cărții respective. Astfel, o însemnare, criticînd mărimea slovelor, este ironică și amuzantă totodată: „Acestor slove le trebuie tarniță, căci sînt prea mari: ar putea aduce cu dînsele mălaiu de la țară!"; autorul anonim al notei se adresează direct copistului, pe un ton dojenitor: „Dar nu-ți iaste mai lesne să le faci mai mici, să nu mînjești cartea, că șeade rău?" ( I, 516). Dacă în majoritatea cazurilor cititorul răspunde pozitiv la invocarea bunăvoinței sale vizavi cu posibilele greșeli, acesta poate deveni și incisiv, criticînd uneori traducerea-„Să vedi că tălmăcitoriul au fost tînăr foarte, căci au poriclit tîlcuirili scriitoriului” (II, 571).

Scrisul izolează, atît scriptorul cît și cititorul rămînînd, fiecare, în singurătatea sa. Acest aspect este, într-o oarecare măsură, eludat de notele marginale. Însemnarea marginală este o formă de dialog orientat, anaforic, spre textul care a generat-o, și cataforic, spre receptorii ulteriori. Două aspecte devin relevante în acest context. Pe de o parte, observăm intruziunea realului în textul ficțional (sau pe marginea lui) în sensul larg al acestui concept—prin cititorul efectiv, biografic (copist, traducător, simplu cititor), care lasă, prin comentariile sale, o urmă de netăgăduit. Pe de altă parte, cartea a avut, la un moment dat, efectul scontat în real: faptul că cititorul a notat ceva în urma lecturii înseamnă că, din virtualitate semantică pe axa paradigmatică, textul și-a actualizat sensul în planul sintagmatic al receptorului, care, din nou, s-a întors asupra textului și l-a glosat. Aceste însemnări, un post-discurs în urma lecturii, devin pentru cei care vor ține, la rîndul lor, volumul respectiv în mînă, un pre-discurs, simbolizînd o deschidere peste timp și generații. Ca o formă de intersubiectivitate, remarcăm un dialog permanent text $\Leftrightarrow$ copist / traducător $\Leftrightarrow$ cititor concret, lanțul nefiind încheiat nici în prezent. Remarcăm această comunicare permanentă între autor și cititor, care face ca textele să palpite, să fie vii, să anuleze diferențele de spațiu sau timp, să fie cu adevărat mijloace de comunicare (într-un sens primar al cuvîntului). De asemenea, însemnările marginale revelează că exista un public-țintă al manuscrisului sau tipăriturii, un cititor avizat într-o oarecare măsură pentru a recepta literatura (în sensul larg al acestui concept). Și, nu în ultimul rînd, numărul mare de cititori care și-au lăsat numele sau impresiile demonstrează o lectură susținută și continuă de-a lungul secolelor. 


\section{Blestemul}

Majoritatea însemnărilor care fixează donația cărții către un lăcaș de cult sau care notifică proprietatea conține diferite blesteme, acestea întărind prestigiul simbolic al cărții. Situat la intersecția dintre religie și magie, blestemul își are originea în credința în puterea cuvîntului. Greutatea imprecaţiei și multitudinea de maledicții îndreptate spre cei care vor face altminteri transformă blestemul într-un mijloc de presiune cu valoare profilactică, avînd un impact asupra mentalului impregnat de spirit religios, provocînd, cel mai probabil în prima perioadă a epocii cercetate, o teamă reală.

Structural, blestemul complet conține mai multe secțiuni: prima parte consemnează interdicția deteriorării actului de donație, după care urmează invocarea (piramidală) a ierarhiilor cerești pentru a pedepsi vinovatul, cu trimiteri la figuri destestabile din istoria creștinismului; secvența justițiară se subdivide, și ea, în proiecția atît a unei pedepse spirituale, cît și a uneia fizice, pămîntești. Bineînțeles, ordinea este comutativă. De asemenea, tiparul blestemului este mereu ajustat de invenție, de creație liberă. Stereotipia este adeseori ruptă de elemente noi, care dau un alt suflu formulelor pietrificate.

Semnificația primă a blestemului este de interdicție. Sînt sancționate în discursul imprecației „stricarea” sau risipirea daniei sub orice formă; sub incidența blestemului vor cădea cei care se vor „ispiti” „s-o vîndă ori s-o fure” (I, 27), aceștia devenind „(je)fuitori de celi sfinti” (III, 448), cine „se încumetă s-o clintească sau s-o ia de la această sfîntă biserică” (I, 81), cei care vor încerca să o distrugă, „să rupă argintul” (I, 52) de pe ea „sau să lipsască slovile aceste în vr-un feli și le strice” (I, 327). Afurisenia acționează nu numai asupra hoțului, ci și asupra rudelor acestuia: „și cini se va ispiti ca să-l furi [...] să fii afurisit pînă la al șaptilea neam, cu tot neamul lui dimpreună” (III, 466). Enumerația victimelor blestemului se transformă uneori într-o radiografie a structurii sociale: „Și oricine, din stăpîni, domni, vlădică, potrupop, preut, ctitori, oameni vlădicești, sau oricine, dieci, mireni, de or călca porunca me, blăstămat și anathema va rămîne” (I, 536).

Încălcarea interdicției atrage după sine pedepsirea vinovatului de către agenți divini (Țighiliu, 1997, p. 300). Pentru împlinirea damnării sînt invocați toți sfinții și toate puterile bisericești. În general, nucleul invocării îl reprezintă blestemul celor 318 (număr reținut prin tradiție) sfinți de la primul sinod ecumenic convocat de împăratul Constantin cel Mare-Sinodul de la Niceea din 325 (Mazilu, 2001, p. 92). De cele mai multe ori însă constatăm o acumulare de forțe împotriva săvîrșirii răului. Monahul Ioil cumpără, la sfirșitul secolului al XVII-lea-începutul celui de-al XVIII-lea o Evanghelie și o donează bisericii din Poiana Ronci „ce esti a hramului Sf(i)tiai Troiță”, încărcînd-o cu un blestem împotriva celui care ar fura-o: „să fie blăstămat de Sf(î)nta Troiță și de Maica Precistă și de cei 12 Apostoli și de Sf(i)nți(i) Pro(o)roci și de Sf(i)nții Mucenici și de Prepodobnici și de Precuvioși și de toță sf(i)nți(i) și de cei 318 Oteță Sf(i)nţi di Nichiia și de cei 70 de Apostoli și de toț(i) sf(i)nții” (I, 328).

$\mathrm{Ca}$ act justițiar, blestemul trebuie să pedepsească. Astfel, o parte însemnată a structurii sale o constituie sancțiunile, pedepsele prescrise la adresa celor vinovați (Radosav, 1997, p. 74). Violența lexicală conturează un imaginar al damnării. Finalitatea proiectată este moartea-fizică și spirituală, în lumea de aici și în lumea de dincolo. Notate pentru a provoca spaima virtualilor culpabili, pentru lumea de dincolo sînt trasate-expresiv—coordonate ale geografiei subpămîntene, locul chinurilor veșnice, iadul (firesc, punctul ultim al blestemului fiind pedeapsa). Urgia dumnezeiască este completată de proiecția diavolului în pedepse. După ce va fi „blestemat și nimicit” de Evangheliști, de cei 318 părinți niceeni și de cei 12 Apostoli, viitorul escatologic al celui care a luat cartea stă sub semnul traiului în comun cu „diavolii cei turbați” (I, 156). Ratarea finalității destinului creștin, anularea șansei îndumnezeirii, excomunicarea din comuniunea cu Dumnezeu corespunde, inevitabil, unei apropieri de lumea opusă. „Și cine a fura-o să fie al 70 de draci și să fii afurisit și să nu-i aibă Dumnezeu de știre şi să fii în iad” (I, 337). Astfel, o imagine a iadului plină de foc, întuneric și scrîșnire a dinților — care și astăzi dăinuie la nivel popular—se desprinde din blestemul celui care ar lua Octoibul donat de popa Vasca bisericii din satul Rîbna Mare: după ce va avea ca pîrîș la Judecată pe „Arhistrategul Mihail” și va fi „blestemat, de trei ori blestemat” de părinții 
de la Niceea, procesul va fi, clar, pierdut: „și casa lui să fie dată judecății Gomorei și sufletul lui iadului celui cumplit, să fie aruncat în focul cel veșnic, unde sînt viermii cei neadormiți și să scrîșnească dinții lui în întunerecul cel din afară” (I, 182). Un alt culpabil care „s-ar ispiti să o furi” este proiectat, aproape folcloric, „,cu toț dieavolii împreună să ste la Iad și talpa Iadului să sprijinască în veci de veci”, blestemul alunecînd spre sudalmă: „să fii afurisit în burduhul dracului, amin” (III, 17). Remarcăm în literatura aceasta a blestemelor concretețea imaginilor care descriu consecințele vizate, gradul de abstractizare fiind redus, în favoarea transparenței mesajului. Intrarea în rău se face la modul cel mai concret. "Și cine să va ispiti să o furi [...] să miargă în focul nestins și în Tartarul cel mai de desupt, și să lăcuiască în burdeiul Dracului” (IV, 552). Magia verbală glisează cu ușurință spre injurie (Mazilu, 2001, p. 249) ca supapă de defulare. O Liturghie conține o descărcare plină de violență, care, cel mai probabil, nu are a face cu furtul de carte. Însemnarea-ocară de la 1773 conturează o traiectorie de desacralizare a blestemului, ieșirea lui de sub egida religiosului și intrarea în sfera laicului trivial: „Pre Radul și cu argatul, să-i ia Dracul și să-i mînince cînii pre cî(m)pi și să fiea despărțiit de creștinii”, încheind, simetric, cu „Mînca-l-ur cînii pre Randul (sic!)” (II, 213).

Pentru a exemplifica mînia lui Dumnezeu, sînt chemate figurile livrești detestabile din istoria creștinismului. Primul care beneficiază de un blestem oficial (cel al Sinodului de la Niceea) este ereticul Arie, o prezență insistentă a blestemelor din însemnări. De asemenea, apar în discursul imprecației figuri ale Vechiului Testament: Cain, primul fratricid, blestemat a fi nomad, veșnic zbuciumat (tradus prin „cutremurul lui Cain”, un Parkinson chinuitor), Core, Datan și Aviron, pedepsiți exemplar deoarece s-au răzvrătit împotriva lui Moise, trădătorul lui Hristos, Iuda; mai este invocată lepra lui Ghezie (Mazilu, 2001, p. 372-375). O variantă complexă și dramatizată a blestemului o scrie monahul Misail pe Psaltirea cumpărată și donată mănăstirii Neamțului: „Iar după moartea mea, cine se va ispiti să îndrăznească să o ia de la această mănăstire sau s-o vîndă în altă parte sau s-o facă să fie a sa, acela să fie blestemat de 318 Părinţi cei din Nicheia și să fie la un loc cu Iuda și cu iudeii care au strigat: ia-l, ia-l, răstignește-l, şi sîngele lui asupra lor. Şi să se afle la judecată cu cel de trei ori blestemat cu Arie și Evnomie și Dioscor și Sevir cel fără cap și să stea la cumplita judecată a lui Hristos de gît cu cei cărora le spune Domnul: plecați de la mine, blestemaților, în focul veșnic pregătit diavolului și îngerilor lui și să fie neiertat de noi, în veci, amin” (I, 91).

Începînd cu secolul al XVIII-lea, o altă maledicțiune este adresată celor care se fac vinovați: neputrezirea. Descompunerea cadavrului simbolizează, în viziunea creștină, reintegrarea în ordinea naturală, (re)întoarcerea la elementele constitutive ale lumii minerale. În unele blesteme accesul la putrefacție este interzis, trupul celui afurisit va rămîne netopit, nedezlegat, i se interzice trecerea, desprinderea de această lume (Țighiliu, 1997, p. 301). Formulele care condamnă la neputrezire urmează, în general, același tipar, cu variații minime: „[...] Lemnele și hierul și pietrele și tote cîte sînt, să putredzască, dar trupul unuia ca aceluia să nu mai putredzască în vecii veacului, și să aibă pîrîși la vreme giudețul pe Svetii Onofrei, a căruia este hramul aice, amin" (I, 412).

Blestemul din însemnările de pe cărțile și manuscrisele vechi este, totodată, topos și invenție. Unele anateme aruncate asupra hoților aproape că provoacă zîmbete prin ineditul și concretețea imaginilor conturate. Astfel, cine ar deposeda pe popa Aron de Penticostarul cumpărat cu propriii bani „să fie afurisit de 318 Sfinți cei din Nicheia şi se intre dracul într-însu, să zbiere ca măgariu cînd îl mănîncă lupii” (I, 519). O altă variantă, dramatizată cu o tentă umoristică, o găsim într-o consemnare de la 1853: „Și cine o va fura, în iad va întra și de acolo va striga dracilor, va zici: lase-mă în paci, că ce-am făcut n-oi mai faci” (IV, 447). Hazul și rima reduc mult din gravitatea blestemului.

\section{Concluzii}

Cartea-tipărită sau manuscris—este, în perioada cercetată, un obiect cultural la care se raportează toate păturile sociale (știutori de carte sau nu), adunînd în jurul ei copiști, vînzători, cumpărători, donatori, cititiori etc., fiind un factor activ, permanent al progresului social. Este foarte prețuită în epoca cercetată, 
pe de o parte, datorită conținutului biblic, sau a mediului mănăstiresc în care erau multiplicate tomurile, pe de altă parte datorită respectului deosebit pentru litera scrisă. Asimilate odoarelor bisericești, referirile la carte se fac aproape în exculsivitate cu epitetele „sfîntă şi dumnezeiască”. Motivul care îi îmbie pe „cei mici” să noteze fapte mari și mărunte pe carte este conștientizarea perenității acesteia: se scrie ca „să se știe”, cartea fiind o punte între timpuri. Dacă la început cărțile sînt un apanaj al bisericii, adresîndu-se individului prin slujba religioasă, pe măsură ce înaintăm temporal spre (pre)modernitate, conținutul acestora se laicizează, cartea devenind o „zăbavă” individuală, demonstrînd o lărgire a preocupărilor culturale. Astfel, printre copiști, traducători, posesori întîlnim atît persoane din rîndurile vieții monahale (călugări, preoți, episcopi, mitropoliți), cît și mireni cu diferite ranguri și ocupaţii.

Tradiția cărții scrise de mînă nu a fost biruită cu ușurință de slova tiparului. Pe tot parcursul perioadei studiate se copie asiduu manuscrise, copiștii avînd un rol important în difuzarea cărții. Semnăturile scribilor sînt, în marea lor majoritate, însoțite de determinanți care arată din plin modestia și umilința lor. Sfidînd granițele spaţiale și temporale, se creează un dialog complex între autorul de manuscris și cititor. Instanță foarte solicitată în însemnări, se conturează două tipuri de cititor-unul abstract, căruia i se adresează autorul umilit, cerînd iertare pentru greșeli, și cel biografic, concret, care își lasă semnătura pe carte. Acesta citește cărțile, le recitește, înțelege sau nu mesajul, compară diferite cărți, iartă pe copist, intră în dialog, la rîndu-i, cu viitori cititori, oferă sfaturi de lectură etc. Uneori se raportează critic la conținutul și forma cărții, critică pe autor / copist, cartea ajungînd, astfel, să conţină și critica sa.

Cartea are însă și caracter de marfă. Vînzarea-cumpărarea este cel mai întîlnit mijloc de distribuție sau circulație a cărții-se vinde la tipografie, la dughene, de către diferiți negustori, la biserici și mănăstiri, în comunitatea sătească și orășenească, oriunde. Însă, pe tot teritoriul românesc și chiar în afara lui, ea circulă și sub alte forme: din generație în generație ca moștenire sau ca zestre, cu titlu de împrumut, ca obiect de schimb, zălogită, furată și răscumpărată. Un fenomen care cunoaște o deosebită amploare în epoca cercetată este dania, donînd atît domni și înalte fețe bisericești, cît și clerici mai mici sau mireni de tot felul.

Un alt aspect care evidențiază valoarea cărții (și nu cea simbolică, de astă dată) este prețul ei. Scumpă, inaccesbilă pentru mulți, ea solicită un efort, deseori colectiv pentru a fi achiziționată.

În epoca cercetată, cartea era un obiect de preț; de aceea, ea va fi încărcată cu un blestem mai mult sau mai puțin înfricoșător, care să o protejeze prin puterea magică a cuvintului de a mobiliza forțe cerești și diavolești împotriva celui care va călca interdicția înstrăinării.

\section{Bibliografie}

\section{A. Izvoare}

Insemnări de pe manuscrise şi cărți vechi din Ţara Moldovei, corpus editat de Ioan Caproşu şi Elena Chiaburu, vol. I-IV, Casa Editorială Demiurg, Iași, 2008-2009.

\section{B. Literatură de specialitate}

Barbu, D. (1996). Scrisoare pe nisip. Timpul și privirea în civilizația românească a secolului al XVIII-lea, Antet, București, p. 76-100.

Chiaburu, E. (2005). Carteși tipar în Țara Moldovei pînă la 1829, Editura Universității „Alexandru Ioan Cuza”, Iași, p. 96-163. Chiperi, M.A. (1996). Vechi însemnări românești ca izvor istoric, Silex, Casă de Editură, Presă și Impresariat, București, p. 13. Ciobanu, Șt. (1947). Istoria literaturii române vechi, vol. I, București, p. 124.

Danielopolu, C. Papacostea \& Demény, L. (1985). Carte și tipar în societatea românească și sud-estul Europei (secolele XVIIXIX), Editura Eminescu, București, p. 121.

Mauss, M. (1993). Eseu despre dar, în românește de Silviu Lupescu, Institutul European, Iași, p. 114-159.

Mazilu, D.H. (2001). O istorie a blestemului, Polirom, p. 92-375.

Ofrim, Al. (2001). Cheia și Psaltirea. Imaginarul cărții în cultura tradițională românească, Editura Paralela 45, p. $129-213$.

Panaitescu, P.P. (1971). Contribuţii la istoria culturii românești, Editura Minerva, București, p. 343.

Platon (2011). Phaidros, în românește de Gabriel Liiceanu, Humanitas, București, p. 126

Radosav, D. (1997). Sentimentul religios la români. O perspectivă istorică (sec. XVII-XX), Editura Dacia, Cluj-Napoca, p. 27131 . 
Stancu, V.P. (2006). Paratextul. Poetica discursului liminar în comunicarea artistică, Editura Universității „Alexandru Ioan Cuza”, Iași, p. 85-131.

Stoicescu, N. (1983). Unitatea românilor în Evul Mediu, Editura Academiei Republicii Socialiste România, București, p. 69. Tomescu, M. (1968). Istoria cărții românești de la începuturi pînă la 1918, Editura Științifică, București, p. 27.

Troia, L. (2005). Cartea veche între fascinație și cunoaștere, Princeps Edit, Iași, p. 5.

Țighiliu, I. (1997). Societate și mentalitate în Țara Românească și Moldova, secolele XV-XVII, Paideia, București, p. 300-301. 